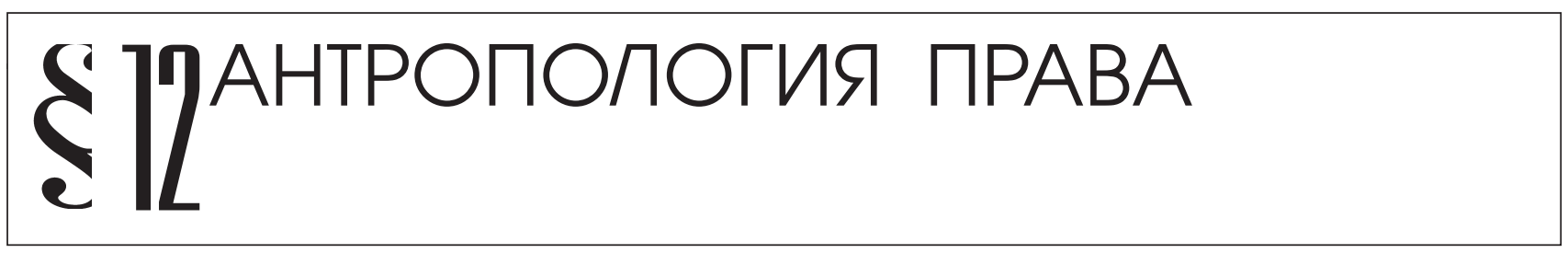

\title{
Н.И. Матузов
}

\section{ПРАВОВОЙ НИГИЛИЗМ КАК ОБРАЗ ЖИЗНИ}

\begin{abstract}
Аннотация: В статье рассматриваются актуальные вопросы правового нигилизма-социальная природа, сущность, содержание, генезис, понятие, определение, источники, формы проявления, степень распространенности, деструктивная роль в развитии современнного российского общества. Показывается, что правовой нигилизм превратился сегодня в серьезный тормоз всех проводимых в стране реформ, модернизаций. Анализируются различные точки зрения и подходы, связанные с трактовкой нигилизма вообще, и правового - в частности. Цель статьи - выявление причин и условий, порождающих правовой нигилизм, определение путей и средств их преодоления. Область использования результатов - учебный и научно-исследовательский процесс в вузах юридического профиля, а такље сфера государственного управления.
\end{abstract}

Ключевые слова: Юриспруденция, право, закон, традиции, нигилизм, правосознание, правонарушение, культура, воспитание, образ жизни

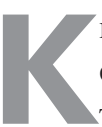
известным двум традиционным бедам России сегодня смело можно прибавить третью - тотальный правовой нигилизм, который имеет столь же глубокие корни, как и первые две напасти. Давно было сказано: на Руси всегда правили люди, а не законы. Отсюда наплевательское отношение к закону как свойство натуры, ментальности русского обывателя. А ведь еще римские юристы провозгласили: государством должен править закон, закон выше любой должности. Это хорошо понимали и отечественные правоведы: «Государство является нравственным настолько, насколько оно управляется законом»' .

Нигилизм вообще, как общесоциальное собирательное понятие, означает в переводе с латинского «ничто», «ничего», «непризнание чего-либо». Нигилизм выражает отрицательное отношение субъекта (группы, класса) к определенным ценностям, нормам, взглядам, идеям, отдельным, а подчас всем устоям человеческого бытия. Девиз нигилистов - все вокруг не так устроено, требует замены.

Нигилизм - одна из форм мироощущения и социального поведения, разновидность фрондерства, бунтарства. Как течение общественной мысли он зародился давно, но наибольшее распространение получил в XIX и XX столетиях, главным образом в Западной Европе и в России. «Но, увы, именно в России нигилизм дал самые обильные всходы»². Характерно название одной из статей того времени․․

1 Чичерин Б.Н. Философия права. М., 1890. С. 70.

${ }^{2}$ Сапронов П.А. Путь в ничто. Очерки русского нигилизма. СПб., 2010. C. 5

${ }^{3}$ Надеждин Н.И. Сонмище нигилистов // Вестник Европы. 1829, № 1-2.
Он был связан с такими философами леворадикального направления, как Якоби, Прудон, Ницше, Штирнер, Хайдеггер, Бакунин, Кропоткин и др. Нигилизм многолик, он может быть нравственным, правовым, политическим, идеологическим, религиозным и т.д., в зависимости от того, какие ценности отрицаются, о какой сфере знаний и социальной практики идет речь - культуре, науке, искусстве, этике, политике, экономике. Нигилизм глубоко укоренился в среде русской разночинной интеллигенции 60-х годов 19 века, отвергавшей феодально-крепостнические порядки и традиции.

Русский писатель И.С. Тургенев вывел в своих романах яркие образы бунтарей, не признававших и осуждавших многие постулаты окружавшей их действительности и предлагавших новые идеи. Нигилистами были революционные демократы, резко критиковавшие современные им порядки и призывавшие к замене их более справедливыми. Нигилизм носил революционный характер. Например, о своем Базарове Тургенев писал, что «если он называется нигилистом, то надо читать: революционером» ${ }^{4}$.

В 1866 г. М.А. Бакунин в знаменитых письмах к А.И. Герцену советовал последнему «искать молодую поросль новой молодежи в недоученных учениках Чернышевского и Добролюбова, в Базаровых, в нигилистах - в них жизнь, в них энергия, в них честная и сильная воля 5 .

Обстоятельная характеристика социального нигилизма, распространившегося в начале XX столетия в опреде-

\footnotetext{
${ }^{4}$ См. Тургенев И.С. Собр. соч.: в 12 т. М., 1958. Т. 12. С. 339.

${ }^{5}$ Письма М.А. Бакунина к А.И. Герцену и Н.П. Огареву. СПб., 1906. C. 293
} 
ленных слоях русского общества, была дана в знаменитом сборнике «Вехи», вышедшем в 1908 г. и получившем впоследствии широкий общественный резонанс. Один из его авторов, а именно С.Л. Франк, с особым пафосом подчеркивал, что если бы можно было одним словом определить умонастроение нашей интеллигенции, то нужно было бы назвать его «морализмом».

«Русский интеллигент, писал С.Л. Франк, не знает никаких абсолютных ценностей, никаких критериев, никакой ориентировки в жизни, кроме морального разграничения людей, поступков, состояний на хорошие и дурные, добрые и злые. Морализм этот есть лишь отражение ее (интеллигенции - Н. М.) нигилизма... Под нигилизмом я разумею отрицание или непризнание абсолютных (объективных) ценностей» ${ }^{6}$.

Общей (родовой) чертой всех форм нигилизма является отрицание, но не всякое отрицание есть нигилизм. Отрицание шире, оно органически присуще человеческому сознанию, диалектическому мышлению. Поэтому далеко не всех, кто что-либо отрицает, можно считать нигилистами. В противном случае сам термин «нигилизм» теряет свой смысл и растворяется в более объемном понятии отрицания.

Следовательно, нигилистическое и диалектическое отрицание - разные вещи. Когда нигилизм становится естественным (объективным) отрицанием старого, заскорузного, реакционного (например, рабства, крепостничества, всех форм деспотизма, порабощения и т.д.), он перестает быть нигилизмом. Равно как отрицание многих мрачных и даже трагических страниц из нашего недавнего прошлого, прежде всего в государственной и политикоправовой сферах жизни общества, вполне справедливо и оправданно, так как представляет собой неизбежный процесс обновления.

Тем более, когда речь идет об эволюционном развитии. Ф. Энгельс, имея в виду движущие силы формационных периодов и смену последних, писал: «Появление молодой буржуазии нашло своё отражение в либеральноконституционном движении, а зарождение пролетариата - в движении, которое обычно называют нигилизмом»7. Здесь термин «нигилизм» употребляется в положительном контексте.

Вообще, гегелевский закон отрицания отрицания никто пока не отменял. Отрицание может быть ради достижения более высоких целей, идеалов; ради устранения диктаторских режимов, тирании. Еще Ж.Ж. Руссо заметил: «Деспот не может жаловаться на свергающее его насилие». Право народа на сопротивление самовластью, угнетению было зафиксировано во французской Декларации прав

\footnotetext{
${ }^{6}$ Франк С.Л. Этика нигилизма // Вехи. Из глубины. М., 1991. С. 170.

${ }^{7}$ Маркс К., Энгельс Ф. Соч., Т. 22. С. 41.
}

человека и гражданина 1789 г. Следовательно, не всякая революция - зло.

Однако в целом нигилизм, в традиционном его понимании, воспринимается в большинстве случаев как явление деструктивное. В толковом словаре В.И. Даля нигилизм однозначно определяется как «безобразное и безнравственное учение, отвергающее все, что нельзя ощупать». В наше время он нередко принимает разрушительные формы. В крайних своих проявлениях нигилизм смыкается с различными анархическими, лево- и праворадикальными устремлениями, всевозможными фобиями, националистическим и политическим экстремизмом. «Нигилизм - стереотип мышления любого радикалиста, даже если он этого не осознает» ${ }^{8}$.

Характерным признаком нигилизма является не объект отрицания, который может быть лишь определителем его конкретного вида, а степень, то есть интенсивность, категоричность и бескомпромиссность этого отрицания - с преобладанием субъективного, чаще всего индивидуального начала. Нигилизм «предполагает некоторую тотальность отрицания, доведенную до предельной полноты» 9 .

Перед нами гипертрофированно выраженное сомнение в известных ценностях и принципах. При этом, как правило, избираются наихудшие способы действия, граничащие с антиобщественным поведением, нарушением моральных и правовых норм. Плюс отсутствие какой-либо позитивной программы или, по крайней мере, ее абстрактность, зыбкость, аморфность. «У нигилиста всегда виноват кто-то, но не он» ${ }^{10}$.

Социальный нигилизм особенно распространился у нас в разгар «перестройки» и «гласности». Именно тогда он с ходу взял бешеный темп, стремительно набирая обороты уже в период «раннего Ельцина» (к концу его правления он достиг своего апогея). Данное явление возникло на волне охватившего страну всеобщего негативизма, когда все и вся переоценивалось, переосмысливалось, осуждалось и отвергалось. С одной стороны, была видна очистительная функция нигилизма, а с другой - его побочные следствия, ибо сплошной поток негатива сметал на своем пути и позитивные начала.

Расчистка авгиевых конюшен сопровождалась такими явлениями, как безудержное самобичевание, развенчание и осмеяние всего прежнего опыта, сложившихся культурноисторических традиций и привычек, изображение уходящего времени только в черных красках. Лейтмотивом этих умонастроений было: «У нас все плохо, у них все хорошо».

\footnotetext{
${ }^{8}$ Демидов А.И. Политический радикализм как источник правового нигилизма // Государство и право. 1992. № 4.

${ }^{9}$ Сапронов П.А. Указ. соч. С. 7.

${ }^{10}$ См.: Золотусский И.П. Нигилисты второй свежести. Иркутск, 2008. C. 6 .
} 


\section{Право и политика $12(156) \cdot 2012$}

С пьедесталов летели имена и ценности, в которые еще вчера беззаветно верили. На крайности этого «самошельмования», потерю меры обращали внимание даже зарубежные деятели, не лишенные чувства здравого смысла.

Зацикленность на обличительстве, уничижительной критике граничила подчас с утратой чувства национальногосударственного достоинства, формировала у людей и всего общества комплекс неполноценности, синдром вины за прошлое, за «исторический грех». Раздавались призывы к всеобщему покаянию. Социально-политический и идеологический нигилизм принимал нередко политически непристойные формы.

Отречение от всего, что было «до того», от старых фетишей, объективно подпитывало нигилистические разрушительные тенденции, которые не уравновешивались созидательными. Как справедливо отмечалось в литературе того времени, «у нас было два пиковых проявления тоталитарного мышления и сознания: тотальная апологетика послереволюционного прошлого и тотальное его ниспровержение» ${ }^{11}$.

Развенчивались герои войны и труда, их подвиги, самопожертвование, дискредитировались и опошлялись неугодные писатели, деятели искусства. Было забыто пушкинское «любовь к родному пепелищу, любовь к отеческим гробам», а также грибоедовское «и дым Отечества нам сладок и приятен». Огульная критика прошлого вызвала резкое недовольство той части российской интеллигенции, которая считала себя национально мыслящей и патриотически настроенной. Она была против «циничных плевков в спину - в сторону отцов, дедов и прадедов» ${ }^{12}$.

Спектр социального нигилизма весьма пестр и богат, переливает всеми цветами радуги. Он может быть «левым», «правым» и «центристским» со множеством полутонов и оттенков. Перед нами достаточно сложное, неоднозначное явление. И отрадно, что в последнее время возникла новая волна интереса к данной проблеме ученых-гуманитариев, которые стали уделять ей все более пристальное внимание - у нас и за рубежом. ${ }^{13}$

Правовой нигилизм - разновидность социального нигилизма как родового понятия. Сущность его-в общем

\footnotetext{
${ }^{11}$ Мушинский В.О. Сумерки тотального сознания // Государство и право. 1992. № 3. С. 80; см. также Кара Мурза. Манипуляция сознанием. М., 2000; Поляков Ю. От империи лжи к республике вранья. М., 1997; Солженицын А.И. Россия в обвале. М., 1998.

12 Золотусский И.П. Указ. соч. С. 96.

${ }^{13}$ См.: Пигалев А.И. Философский нигилизм и кризис культуры. Саратов, 1991; Ципко А.С. Почему я не «демократ». Критика национального нигилизма российских либералов. М., 2005; Золотусский И.П. Нигилисты второй свежести. Раздумья на исходе эпохи. Иркутск, 2008; Сапронов П.А. Путь в ничто. Очерки русского нигилизма. СПб, 2010; Краус В. Нигилизм и идеалы. Пер. с нем., М., 1994; Юнгер Э., Хайдеггер М., Кампер Д., Фигаль П. Судьба нигилизма. Пер. с нем., М., 2006.
}

негативно-отрицательном, неуважительном отношении к праву, законам, нормативному порядку, а с точки зрения корней, причин - в юридическом невежестве, косности, отсталости, правовой невоспитанности основной массы населения. Подобные антиправовые установки и стереотипы есть «элемент, черта, свойство общественного сознания и национальной психологии, отличительная особенность культуры, традиций, образа жизни» ${ }^{14}$.

Одним из ключевых моментов здесь выступает надменно-пренебрежительное, высокомерное, снисходительно-скептическое восприятие права, оценка его не как базовой, фундаментальной идеи, а как второстепенного явления в общей шкале человеческих ценностей, что, в свою очередь, характеризует меру цивилизованности общества, состояние его духа, умонастроений, социальных чувств, привычек.

Неверие в высокое предназначение, возможности и даже необходимость права - таков морально-психологический генезис данного феномена. Наконец, отношение к праву может быть просто индифферентным (безразличным), что тоже свидетельствует о неразвитом правовом сознании людей, об ущербности их менталитета. В конечном счете речь идет о невостребованности права обществом, нелюбовь к порядку.

Корни же этого недуга уходят в далекое прошлое. Для нашей страны это - устойчивая многовековая традиция, которую признавали все передовые мыслители российского общества и сильно сокрушались по данному поводу. Расхожими стали печальные слова Герцена о том, что жить в России и не нарушать законов нельзя. «Русский, какого бы звания он ни был, обходит или нарушает закон всюду, где это можно сделать безнаказанно; совершенно так же поступает и правительство» ${ }^{15}$. С этим созвучна не менее популярная мысль Салтыкова-Щедрина: суровость российских законов смягчается необязательностью их исполнения. Щедринский градоначальник так и советовал: «Ежели чувствуешь себя в своей деятельности в чем-то стесненным законом, то, сняв оный со стола, положи его под себя». А еще классик не без сарказма писал: «Российская власть обладает способностью держать свой народ в состоянии постоянного изумления».

Следовательно, правовой нигилизм исходит не только от простых обывателей, но и от «столоначальников», то есть как снизу, так и сверху. Подобная ситуация сохранятся до сих пор. И трудно сказать, что опаснее, вреднее-первое или второе. Думается, что бюрократический, чиновничий нигилизм, основанный на всевластии государственной элиты, является более разрушительным и ведет к далеко идущим последствиям.

\footnotetext{
${ }^{14}$ Туманов В.А. О правовом нигилизме // Советское государство и право. 1989. № 10. С. 20.

${ }^{15}$ Гериен А.И. Соч. Т. 7. М., 1950. С. 251.
} 
Историк В.О. Ключевский с горечью признавался: «Не я виноват в том, что мало обращаю внимания на право: меня приучила к этому русская жизнь, не знавшая никакого права» ${ }^{16}$. В.Г. Белинский в письме к Н.В. Гоголю в сердцах заметил: в России «нет даже полицейского государства, есть только огромные корпорации воров и грабителей». В то время это было общим взглядом творческих деятелей на окружающую их действительность. Известны крайне отрицательные суждения Л.Н. Толстого о праве, который называл его «гадким обманом властей», насилием над личностью.

Даже такой ценитель и проповедник права, как Б.А. Кистяковский, в известной статье в защиту права пишет: «Право не может быть поставлено рядом с такими духовными ценностями, как научная истина, нравственное совершенство, религиозная святыня. Значение его более относительно» ${ }^{17}$.

Как видим, данное высказывание отводит праву не первое и даже не второе или третье место в общем культурном наследии человечества, оно отодвигается автором куда-то на периферию общественного прогресса. Все это, как пишет тот же Б.А. Кистяковский, дало повод одному из тогдашних поэтов-юмористов сочинить следующие довольно едкие, но остроумные стихи:

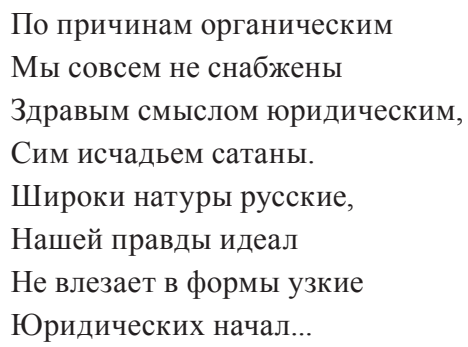

Таковы отечественные правовые традиции, культура, привычки, образ жизни. К сожалению, мы не только не избавились от этого застарелого порока, но в полной мере унаследовали его, а во многом «обогатили». На протяжении длительного времени право в обществе «развитого социализма» всячески умалялось, в нем не видели истинно демократического и краеугольного института, высокой социальной и моральной ценности. Предпочтение отдавалось экономике, политике, идеологии, партийной линии. Идеи же права нередко третировались, отрицались. Так, в середине 20-х годов минувшего столетия М.А. Рейснер издевательски писал: «Если право не «опиум» народа, то, во всяком случае, довольно опасное снадобье» ${ }^{18}$. Несколько

\footnotetext{
${ }^{16}$ Ключевский В.О. Письма. Дневники. Афоризмы. М., 1968. С. 378.

${ }^{17}$ Кистяковский Б.А. В защиту права. Интеллигенция и правосознание // Вехи. Из глубины. М., 1991. С. 122.

${ }_{18}$ Рейснер М.А. Право. Наше право, чужое право, общее право. M., 1925. C. 35.
}

мягче высказывание Е.Б. Пашуканиса: «Мы за то, чтобы в праве на первом месте стояла политика, чтобы политика довлела над правом»19. Какова была политика в то время, хорошо известно.

Право, скорее, терпели как необходимое декоративное украшение, формальный атрибут, фасад, свойственные любому «благопристойному» обществу. Но в целом оно считалось «неполноценной и даже ущербной формой социальной регуляции, лишь на время и лишь в силу печальной необходимости заимствованной у прежних эксплуататорских эпох» ${ }^{20}$. Право должно было «отмереть». На практике осуществлялась ленинская идея, согласно которой в основе социалистического государства лежит диктатура пролетариата, представляющая собой «ничем не ограниченную, никакими правилами не стесненную, опирающуюся непосредственно на силу, а не на закон, власть» ${ }^{21}$. Уже в этом заключался главный изначальный источник правового нигилизма, носившего по сути официальный характер.

Таким образом, правовой нигилизм имеет в нашей стране благодатнейшую почву, которая всегда давала и продолжает давать обильные всходы, причем эта почва постоянно удобряется, так что «неурожайных» лет практически не было. При этом современное содержание правового нигилизма вышло далеко за рамки простого неуважения или несоблюдения права; в условиях нынешней России оно (содержание) означает нечто гораздо большее.

В этой связи трудно согласиться с мнением, согласно которому правовой нигилизм - всего лишь «сознательное игнорирование требований закона, исключающее, однако, преступный умысел», а «игнорирование закона с преступной целью представляет собой самостоятельную форму деформации правосознания» ${ }^{22}$. С этой точки зрения правовой нигилизм остается таковым только до тех пор, пока он не доходит до стадии сознательного нарушения правовых норм; он означает лишь непризнание права, отсутствие веры в его социальную значимость. ${ }^{23}$

Конечно, хорошо, если бы дело было именно так. Тогда правовой нигилизм представлял бы собой хотя и нежелательное, но все же сравнительно безобидное явление. В приведенных суждениях по сути дела отрицается тот факт, что умышленные правонарушения и в частности преступления есть форма проявления правового ниги-

\footnotetext{
${ }^{19}$ Пашуканис Е.Б. Положение на теоретическом правовом фронте // Советское государство и революция права. 1930. № 11/12. С. 8 .

${ }^{20}$ Соловьев Э.Ю. Правовой нигилизм и гуманитарный смысл права // Квинтэссенция: Философский альманах. М., 1990. С. 164.

${ }^{21}$ Ленин В.И. Полн. собр. соч., Т. 41, С. 376.

${ }^{22}$ Баранов В.М. Правосознание и правовое воспитание // Общая теория права. Под ред. В.К. Бабаева. Н.- Новгород, 1993, С. 482.

${ }^{23}$ См.: Кулапов В.Л. Теория государства и права. Учебное пособие. Саратов, 2005, С. 341.
} 


\section{Право и политика $12(156) \cdot 2012$}

лизма. Получается, что если человек просто не уважает или игнорирует закон - это нигилизм, а если он при этом его еще и нарушает - это не нигилизм, а нечто другое. Нелогично.

Мы же полагаем, что злостный, корыстный, уголовный криминал - наиболее грубый и опасный вид правового нигилизма. Преступность - мощный источник и в тоже время крайняя форма выражения нигилизма. Из этого огромного бастиона и рассадника зла берут свое начало многие другие социальные аномалии. Это, кстати, не мешает видеть в преступлениях и «самостоятельную форму деформации правосознания». Одно не исключает другое. В случае с преступностью речь идет не просто об игнорировании или неуважении закона, а о его прямом, преднамеренном попрании. Иная позиция была бы, на наш взгляд, странной и непоследовательной. Впрочем, вопрос дискуссионный и требует обсуждения. Любое мнение по столь сложной и неоднозначной проблеме имеет право на существование.

Надо сказать, что в советский период проблема правового нигилизма практически не ставилась и не исследовалась или, точнее, замалчивалась, хотя в реальной жизни постоянно присутствовала, причем в самых грубых и жестоких формах (массовые репрессии, беззакония, борьба с «врагами народа» и т.д.). Она стала привлекать к себе внимание лишь на исходе «перестройки» и затем с началом реформации. Появились первые публикации - статьи, диссертации, монографии. Не оставалась в стороне пресса, не отмалчивались, как прежде, официальные структуры, представители власти. Проблема перешла в разряд «обсуждаемых» и причем все более активно. ${ }^{24}$

Сегодня главная причина неуважительного, мягко говоря, отношения к закону — продолжающийся системный кризис общества. Криминогенная действительность, политическая напряженность, экономические неурядицы, пауперизм, алкоголизация и наркоманизация части населения, разгул преступности, чиновничий беспредел, коррупция, расхождение слов и дел, неравенство перед за-

${ }^{24}$ См.: Туманов В.А. о правовом нигилизме // Государство и право. 1989, № 10; он же. Правовой нигилизм в историко-идеологическом ракурсе // Государство и право. 1993, № 8; Матузов Н.И. Правовой нигилизм и правовой идеализм как две стороны «одной медали» // Правоведение. 1994, № 2; он же. Правовой нигилизм как явление российского политического менталитета // Право и жизнь, 2002, № 47 ; Попов B.B. Некоторые формы проявления правового нигилизма и пути их преодоления // Юрист, 2002, № 1; Горохов П.А. Социальная природа правового нигилизма. Оренбург. 1998; Гулина О.Р. Феномен правового нигилизма в современной России. Уфа, 2003; Варламова Н.В. Правовой нигилизм: прошлое, настоящее и будущее России // Конституционное право. Восточно-Европейское обозрение. 2000, № 1; Гуляихин В.Н. Правовой нигилизм в России. Волгоград, 2005; Зрячкин А.Н. Правовой нигилизм: причины и пути их преодоления. Саратов, 2009; Чайкин Э.В. Синдром русского треугольника. Антология правового нигилизма в России. М., 2010. коном и судом, социальная несправедливость, не знающий аналогов в мире разрыв между «очень богатыми» и «очень бедными», уродливый российский капитализм и многое другое постоянно воспроизводят правовой нигилизм в геометрической прогрессии.

Он стал опасной хронической болезнью, поразившей все звенья и структуры государства, весь его организм. И в то же время образом жизни, его негативной стороной. Как это ни прискорбно, но традиционное разгильдяйство, расхлябанность, неприученность к порядку, дисциплине, организованности давно считаются национальными чертами российского менталитета. Но явление это, безусловно, социального, а не естественного происхождения. Нигилизм по наследству не передается, он не в генах, а в ментальности. Это социальная патология.

Некомпетентность и неэффективность власти, утрата доверия к ней - один из глубинных источников правового нигилизма. Отсюда неверие в право, закон, справедливость. По данным социологов, примерно половина российских граждан не доверяют органам МВД, прокуратуры, суда. Дают о себе знать рецидивы политико-правового хаоса «лихих-девяностых» с их криминальными разборками «по понятиям», по праву сильного.

Наряду с правоохранительными органами действуют «левоохранительные». Именно поэтому страна нуждается не только в социально-экономической и политической стабильности, но и в правовой. Более того, правовая стабилизация, последовательное соблюдение порядка и законности, может в немалой степени способствовать упрочению положения дел во всех других областях, ибо правовая дисциплина лежит в основе общегосударственной.

Надо сказать, что ныне действующая Конституция РФ призвана была с самого начала стать главным консолидирующим фактором жизни страны, способным сплотить общество. Проблема, однако, в том, что разработанная в спешке «победившей» стороной и принятая с многочисленными нарушениями на референдуме в 1993 г. Конституция имеет явно недостаточную легитимность и социальную базу (поддержана лишь одной третью избирателей, 14 субъектов Федерации вообще за нее не голосовали, 17 проголосовали против), что затрудняет достижение на ее основе гражданского мира и согласия.

Конституция была создана «под Ельцина», с «фараонскими» для него полномочиями, поэтому в прессе ее окрестили «персональной». Она не выражала действительного соотношения политических сил того времени; не выражает и сейчас. Не случайно в последнее время всё более активно выдвигаются предложения о внесении в нее поправок, изменении конституционной политики вообще ${ }^{25}$.

\footnotetext{
${ }^{25}$ См.: Добрынин Н.М. Конституционализация - ожидаемое или норма жизни? // Государство и право. 2010. № 5; Васильев В.И. Гарантии есть, а выхода - нет. Основной закон страны уже не
} 
Указанное обстоятельство в значительной мере снижает моральный авторитет и реальную силу Конституции. Юридически же жить по ней обязаны все. У определенной части населения налицо внутренний конфликт между несогласием с предложенным в свое время проектом и внешней необходимостью соблюдения уже принятого Основного Закона. А это еще один источник правового и нравственного нигилизма, ибо психологическая раздвоенность личности не позволяет ей сформировать четкую и активную гражданскую позицию в отношении нынешнего политико-правового статус-кво.

Иными словами, существует не только общеправовой, но и конституционный нигилизм, который является юридическим выражением несогласия большинства людей с властью. Получается, что одним из источников правового нигилизма выступает сама Конституция с ее «загогулинами», изъянами, недомолвками, «скрытыми полномочиями». К сожалению, она объективно генерирует правовой нигилизм. К тому же нередко нарушается - как властью, ее чиновниками, так и «простыми смертными».

Таким образом, один из глубинных источников правового нигилизма коренится в отчужденности граждан от Основного Закона, как, впрочем, и от других основополагающих актов; во внутреннем неприятии их в качестве «своих», то есть подлинно легитимных. Между тем «честным, законопослушным можно быть только по личной убежденности, в силу личного решения. Без этого нет правосознания и лояльности, и гражданин становится не опорой, а брешью в правопорядке» ${ }^{26}$.

Иными словами, важно, чтобы человек «свободною душой закон боготворил» (А.С. Пушкин), а не по принуждению, не из-под палки. Именно поэтому следует различать законопослушание и законоуважение. Законопослушное поведение основано чаще всего на страхе, принуждении, в то время как законоуважение - на глубоком осознании необходимости следовать закону, праву. То есть это добровольная позиция индивида. Не зря говорят: честный гражданин плюс закон - уже большинство.

Правовой нигилизм - продукт социальных отношений, он обусловлен множеством причин и следствий. В частности, он подпитывается и такими реалиями наших дней, как политиканство, циничный популизм лидеров всех рангов, борьба позиций и амбиций, самолюбий и тщеславий. Дают о себе знать эгоизм и корысть бюрократии, некомпетентность и бестолковость чиновников. Последнее - традиционно больное место нашей отечественной государственности. Пушкинское «он чином от ума избавлен» подтверждается на каждом

отвечает запросам на перемены // НГ - Политика. 2012. 6 марта; Реформа Конституции РФ - ящик Пандоры или насущная необходимость? // НГ-Политика, 2012, 17 апреля.

${ }^{26}$ Ильин И.А. Наши задачи. М., 1993. С. 182. шагу. Полузнайство, невежество, дилетантство, а также банальное разгильдяйство разрушают всякую правовую ткань, любые разумные юридические установления.

На личностном уровне правовой нигилизм выступает в двух ипостасях: как состояние умов, чувств, настроений и как образ действий, линия поведения. Именно действие - непосредственный индикатор вредности и опасности явления. Поступки - плоды помыслов, поэтому не иначе как по поступкам, действиям можно судить о самом наличии и последствиях правового нигилизма. Он может быть активным и пассивным, стойким и спонтанным, постоянным и ситуативным, проявляться в виде простого фрондерства, иметь личные причины, когда, скажем, гражданин недоволен судом только потому, что он его судил, а закон плох потому, что предусмотрел наказание за совершенное им деяние. Это бытовой уровень правосознания.

Не последними причинами правового и нравственного нигилизма являются изъяны в следственно-прокурорской и судебной практике. Давно было подмечено: есть два способа разложить нацию - наказывать невиновных и не наказывать виновных. У нас, к сожалению, допускается и то и другое. Парадоксы правосудия травмируют правосознание людей, их представления о справедливости. А ведь еще древние римляне утверждали: недоверие к судьям есть начало разложения общества.

Следует различать источники и причины правового нигилизма, хотя непроходимой пропасти между ними нет. Источники, как правило, носят более глубинный, постоянный и трудноустранимый характер (например, низкий уровень культуры и правосознания населения, социальные условия, бедность, нищета, преступность и другие факторы). Причины же более скоротечны, разнообразны, они могут появляться и исчезать или устраняться. Источники - питательная среда для появления причин. При этом определенные обстоятельства могут одновременно выступать и как источник, и как причина, и как форма выражения правового нигилизма. К примеру, та же преступность. Всякие градации здесь условны, неабсолютны.

Ежедневно и ежечасно культивирует правовой и нравственный нигилизм наше российское телевидение (насилие, жестокость, агрессия, пошлость), которое ныне покойный академик Виталий Гинзбург не без оснований назвал «преступной организацией». Все это создает негативную атмосферу антикультуры и безответственности в обществе $^{27}$. Не случайно некоторые аналитики ставят вопрос о необходимости соблюдения информацчионной экологии,

\footnotetext{
${ }^{27}$ См. подробнее: Бондарев А.С. Правовая антикультура в правовом пространстве общества. Пермь, 2006. Он же. Юридическая ответственность и безответственность - стороны правовой культуры и антикультуры субъектов права. СПб, 2008 г.
} 


\section{Право и политика $12(156) \cdot 2012$}

ибо сегодня загрязняется не только природная среда, но и социальная, в данном случае информационно-медийная. И еще не известно, какая среда приносит наибольший вред.

Произошла девальвация моральных и чисто человеческих ценностей: «честность», «порядочность», «стыд», «совесть», «долг», «сострадание». Падение же морали неизбежно порождает правовой нигилизм, неуважение к «каким-то там законам», предписаниям. Давно было сказано: бессмысленны законы в безнравственной стране. Многие люди не задают себе никаких «каверзных» вопросов, не ставят никаких целей, легко переходят грань между добром и злом, дозволенным и недозволенным. Модным стал девиз: «успех любой ценой». Такие черты, как жадность, стяжательнось уже не очень-то и порицаются. А ведь еще древние расценивали жадность как «пропасть, в которую можно падать вечно».

Поэтому важно приучить людей к тому, что жить по закону выгодно, прилично комфортно, что это признак хорошего тона, культуры, интеллигентности. И, напротив, жить вопреки закону - позорно, аморально, небезопасно. Древние римляне говорили: кто живет по закону, тот никому не вредит. А народная мудрость гласит: если хочешь крепко спать, возьми с собой в постель чистую совесть. Вспоминается и пушкинское: «жалок тот, в ком совесть нечиста». В идеале соблюдение законов должно стать для каждого человека «второй натурой», нормальным, обычным образом жизни. Но это в идеале, реальность же, увы, другая.

Международные эксперты оценивают наше постсоветское законодательство на четверку - оно, по их мнению, в целом вполне прогрессивно и демократично, а за его соблюдение, исполнение, претворение в жизнь ставят жирную двойку. Тем самым они констатируют, что у нас процветает правовой нигилизм прежде всего на уровне правореализации. А в этом случае самые мудрые и совершенные законы лишаются смысла. Именно это является нашей «ахиллесовой пятой». Для многих законы становится весьма условным понятием: нравится — повинуюсь, не нравится - игнорирую. Еще больший нигилизм порождают законы, которые невозможно исполнить, а таковые есть.

Власть на всех уровнях поражена вирусом неправового сознания. Расхожая мысль о том, что законы пишутся для того, чтобы их нарушать, нередко у нас, к сожалению, оправдывается. Безграничен ведомственный правовой нигилизм. Вся ткань российского общества пропитана правовым нигилизмом. Каждый рассуждает: закон не для меня, он для других. Многие даже бравируют тем, что удалось обойти закон, схитрить, словчить. Подается это как «уменье жить», дескать «не украдешь - не проживешь». А законопослушных граждан представляют как неудачников, наивных чудаков не от мира сего.

Воровство - одно из распространенных и позорных проявлений правового нигилизма; воровство - мелкое, бытовое и крупное, как правило, чиновничье. Когда-то
Н.М. Карамзин (1766-1826) по приезде в Париж на вопрос. «Как там в России?» - ответил: «Воруют». Он же в одной из записок Царю взывал: «Дайте нам два десятка честных губернаторов, и мы спасем отечество». В исторической литературе не раз приводились слова российского императора Николая I, который якобы пожаловался однажды своему наследнику: «Похоже, в России не крадут только двое - ты да я». Известная сентенция «не пойман - не вор» все чаще сегодня в народе перефразируется: «Не пойман, но вор».

Криминальная статистика называет «астрономические» цифры коррупционных дел, число чиновниковвзяточников и взяткодателей разного уровня и ранга. Сложился поистине «всемогущий, всеберущий, всеворующий союз» (Н.А. Некрасов). Это своего рода «элитный нигилизм», нигилизм «белых воротничков», т.е. власти. Мы наблюдаем сегодня правовой цинизм властных структур и правовой нигилизм подвластных.

В свое время М.M. Сперанский назвал регионы Империи «дном беззакония». С тех пор мало что изменилось. Правда, губернаторская «вольница», которая была при Ельцине, давно закончилась. Но и при «вертикале власти» нарушений законов и законности хватает. Причем исходит все это прежде всего от бюрократии, чиновничества, «слуг народа». Сосредоточение всей полноты политической воли на самой вершине управленческой пирамиды напоминает известный афоризм дореволюционного публициста В.А. Гиляровского о том, что в России две напасти: внизу власть тьмы, а наверху — тьма власти. Опасная диспропорция, приводящая, как правило, к социальным катаклизмам. Тем более что власти никогда не бывает много на любом уровне.

Одна из самых серьезных форм проявления юридического нигилизма и вместе с тем его постоянный источник - это слабая правовая защищенность личности, которая подрывает веру в закон, в способность государства обеспечить порядок и спокойствие в обществе, оградить людей от криминального разгула. Бессилие же права не может породить позитивного отношения к нему, а, напротив, вызывает лишь раздражение, недовольство, протест. Право как бы само продуцирует нигилизм. Человек перестает уважать, почитать право, так как он не видит в нем своего надежного гаранта и опоры. В таких условиях даже у законопослушных граждан вырабатывается нигилизм, недоверие к существующим институтам, вызывает правовую разочарованность, скепсис.

Подытоживая все сказанное, можно выделить некоторые общие, наиболее характерные черты и особенности современного правового нигилизма в России. Это:

во-первых, его подчеркнуто демонстративный, воинствующий, цинично-агрессивный характер, не влекущий никакой ответственности, что обоснованно квалифицируется общественным мнением как беспредел или запредельность, отождествляется с хаотизацией общества; 
во-вторых, массовость, тотальность, широкая распространенность не только среди граждан, социальных и профессиональных групп, слоев, кланов, но и в официальных государственных структурах, законодательных, исполнительных и правоохранительных эшелонах власти;

в-третьих, многообразие форм проявления - от криминальных до легальных, от парламентско-конституционных до митингово-анархических и охлократических, от «верхушечных» до бытовых; для многих он стал образом жизни, привычной повседневностью;

в-четвертых, особая степень вредности, разрушительности; оппозиционная и конфронтационная направленность, нередко принимающая форму «вызова», «абструкции», «подстрекательства»; в моде не позитив, а негатив; распространились разного рода фобии, вражда, нетерпимость, проявления экстремизма.

в-пятых, слияние с государственным, политическим, нравственным, духовным, культурным, национальным, интеллектуальным нигилизмом, образующими вместе единый деструктивный процесс, ведущий в конечном счете к дестабилизации общества;

в-шестых, связь с негативизмом - более широким течением, захлестнувшим в последние годы сначала советское, а затем российское общество в ходе демонтажа старой и создания новой системы, смены образа жизни, социальных и нравственных ориентиров; доминирование разрушительных тенденций над созидательными;

в-седьмых, огульная критика и отрицание всего и вся по радикальному принципу «чем хуже, тем лучше», исходящая от определённых сил и групп, вовлеченных в острую политическую борьбу с властью и конфликтующих с ней. Преобладают лозунги не «за», а «против». Умником считается тот, кто больше всех отрицает и порицает. Помимо «телефонного права» появилось «митинговое правосудие».

В итоге правовой нигилизм можно определить как психологически отрицательное (негативное) отношение к праву со стороны граждан, должностных лии, государственных и общественных структур, а также фактические правонарушающие действия указанных субъектов; феномен, выступаюший в качестве элемента общественного сознания, образа жизни, ментальности, способ, линия поведения индивида либо коллектива.

\section{Библиография}

1. Чичерин Б.Н. Философия права. М., 1890. С. 70.

2. Сапронов П.А. Путь в ничто. Очерки русского нигилизма. СПб., 2010. С. 5.

3. Надеждин Н.И. Сонмище нигилистов // Вестник Европы. 1829, № 1-2.
4. Тургенев И.С. Собр. соч.: в 12 т. М., 1958. Т. 12. С. 339.

5. Письма М.А. Бакунина к А.И. Герцену и Н.П. Огареву. СПб., 1906. С. 293.

6. Франк С.Л. Этика нигилизма // Вехи. Из глубины. М., 1991. С. 170.

7. Маркс К., Энгельс Ф. Соч., Т. 22. С. 41.

8. Демидов А.И. Политический радикализм как источник правового нигилизма // Государство и право. 1992. № 4.

9. Золотусский И.П. Нигилисты второй свежести. Иркутск, 2008. С. 6.

10. Мушинский В.О. Сумерки тотального сознания // Государство и право. 1992. № 3. С. 80;

11. Кара Мурза. Манипуляция сознанием. М., 2000.

12. Поляков Ю. От империи лжи к республике вранья. М., 1997.

13. Солженицын А.И. Россия в обвале. М., 1998.

14. Пигалев А.И. Философский нигилизм и кризис культуры. Саратов, 1991.

15. Ципко А.С. Почему я не «демократ». Критика национального нигилизма российских либералов. М., 2005.

16. Золотусский И.П. Нигилисты второй свежести. Раздумья на исходе эпохи. Иркутск, 2008.

17. Краус В. Нигилизм и идеалы. Пер. с нем., М., 1994.

18. Юнгер Э., Хайдеггер М., Кампер Д., Фигаль П. Судьба нигилизма. Пер. с нем., М., 2006.

19. Туманов В.А. О правовом нигилизме // Советское государство и право. 1989. № 10. С. 20.

20. Герцен А.И. Соч. Т. 7. М., 1950. С. 251.

21. Салтыков-Щедрин М.Е. Собр. Соч. в 20 Т. 8. М., 1969. C. 292.

22. Ключевский В.О. Письма. Дневники. Афоризмы. М., 1968. С. 378.

23. Кистяковский Б.А. В защиту права. Интеллигенция и правосознание // Вехи. Из глубины. М., 1991. С. 122.

24. Рейснер М.А. Право. Наше право, чужое право, общее право. М., 1925. С. 35.

25. Пашуканис Е.Б. Положение на теоретическом правовом фронте // Советское государство и революция права. 1930. № 11/12. С. 8.

26. Соловьев Э.Ю. Правовой нигилизм и гуманитарный смысл права // Квинтэссенция: Философский альманах. М., 1990. С. 164.

27. Ленин В.И. Полн. собр. соч., Т. 41, С. 376.

28. Баранов В.М. Правосознание и правовое воспитание // Общая теория права. Под ред. В.К. Бабаева. Н.Новгород, 1993, С. 482.

29. Кулапов В.Л. Теория государства и права. Учебное пособие. Саратов, 2005, С. 341.

30. Туманов В.А. о правовом нигилизме // Государство и право. 1989. № 10.

31. Туманов В.А. Правовой нигилизм в историко-идеологическом ракурсе // Государство и право. 1993. № 8. 
32. Матузов Н.И. Правовой нигилизм и правовой идеализм как две стороны «одной медали»// Правоведение. 1994, № 2.

33. Матузов Н.И. Правовой нигилизм как явление российского политического менталитета // Право и жизнь, 2002, № 47.

34. Попов В.В. Некоторые формы проявления правового нигилизма и пути их преодоления // Юрист, 2002, № 1.

35. Горохов П.А. Социальная природа правового нигилизма. Оренбург. 1998.

36. Гулина О.Р. Феномен правового нигилизма в современной России. Уфа, 2003.

37. Варламова Н.В. Правовой нигилизм: прошлое, настоящее и будущее России // Конституционное право. Восточно-Европейское обозрение. 2000, № 1.

38. Гуляихин В.Н. Правовой нигилизм в России. Волгоград, 2005.

39. Зрячкин А.Н. Правовой нигилизм: причины и пути их преодоления. Саратов, 2009.

40. Чайкин Э.В. Синдром русского треугольника. Антология правового нигилизма в России. М., 2010.

41. Добрынин Н.М. Конституционализация - ожидаемое или норма жизни? // Государство и право. 2010. № 5.

42. Васильев В.И. Гарантии есть, а выхода - нет. Основной закон страны уже не отвечает запросам на перемены // НГ - Политика. 2012. 6 марта.

43. Реформа Конституции РФ - ящик Пандоры или насущная необходимость? // НГ-Политика, 2012, 17 апреля.

44. Ильин И.А. Наши задачи. М., 1993. С. 182.

45. Бондарев А.С. Правовая антикультура в правовом пространстве общества. Пермь, 2006.

46. Бондарев А.С. Юридическая ответственность и безответственность - стороны правовой культуры и антикультуры субъектов права. СПб, 2008.

\section{References (transliteration):}

1. Chicherin B.N. Filosofiya prava. M., 1890. S. 70.

2. Sapronov P.A. Put' v nichto. Ocherki russkogo nigilizma. SPb., 2010. S. 5.

3. Nadezhdin N.I. Sonmishche nigilistov // Vestnik Evropy. 1829, № 1-2.

4. Turgenev I.S. Sobr. soch.: v 12 t. M., 1958. T. 12. S. 339.

5. Pis'ma M.A. Bakunina k A.I. Gertsenu i N.P. Ogarevu. SPb., 1906. S. 293.

6. Frank S.L. Etika nigilizma // Vekhi. Iz glubiny. M., 1991. S. 170.

7. Marks K., Engel's F. Soch., T. 22. S. 41.

8. Demidov A.I. Politicheskiy radikalizm kak istochnik pravovogo nigilizma // Gosudarstvo i pravo. 1992. № 4.

9. Zolotusskiy I.P. Nigilisty vtoroy svezhesti. Irkutsk, 2008. S. 6.
10. Mushinskiy V.O. Sumerki total'nogo soznaniya // Gosudarstvo i pravo. 1992. № 3. S. 80;

11. Kara Murza. Manipulyatsiya soznaniem. M., 2000.

12. Polyakov Yu. Ot imperii lzhi k respublike vran'ya. M., 1997.

13. Solzhenitsyn A.I. Rossiya v obvale. M., 1998.

14. Pigalev A.I. Filosofskiy nigilizm i krizis kul'tury. Saratov, 1991.

15. Tsipko A.S. Pochemu ya ne «demokrat». Kritika natsional'nogo nigilizma rossiyskikh liberalov. M., 2005.

16. Zolotusskiy I.P. Nigilisty vtoroy svezhesti. Razdum'ya na iskhode epokhi. Irkutsk, 2008.

17. Kraus V. Nigilizm i idealy. Per. s nem., M., 1994.

18. Yunger E., Khaydegger M., Kamper D., Figal' P. Sud'ba nigilizma. Per. s nem., M., 2006.

19. Tumanov V.A. O pravovom nigilizme // Sovetskoe gosudarstvo i pravo. 1989. № 10. S. 20.

20. Gertsen A.I. Soch. T. 7. M., 1950. S. 251.

21. Saltykov-Shchedrin M.E. Sobr. Soch. v 20 T. 8. M., 1969. S. 292.

22. Klyuchevskiy V.O. Pis'ma. Dnevniki. Aforizmy. M., 1968. S. 378.

23. Kistyakovskiy B.A. V zashchitu prava. Intelligentsiya i pravosoznanie // Vekhi. Iz glubiny. M., 1991. S. 122.

24. Reysner M.A. Pravo. Nashe pravo, chuzhoe pravo, obshchee pravo. M., 1925. S. 35.

25. Pashukanis E.B. Polozhenie na teoreticheskom pravovom fronte// Sovetskoe gosudarstvo i revolyutsiya prava. 1930. № $11 / 12$. S. 8.

26. Solov'ev E.Yu. Pravovoy nigilizm i gumanitarnyy smysl prava // Kvintessentsiya: Filosofskiy al'manakh. M., 1990. S. 164.

27. Lenin V.I. Poln. sobr. soch., T. 41, S. 376.

28. Baranov V.M. Pravosoznanie i pravovoe vospitanie // Obshchaya teoriya prava. Pod red. V.K. Babaeva. N.Novgorod, 1993, S. 482.

29. Kulapov V.L. Teoriya gosudarstva i prava. Uchebnoe posobie. Saratov, 2005, S. 341.

30. Tumanov V.A. o pravovom nigilizme // Gosudarstvo i pravo. 1989. № 10.

31. Tumanov V.A. Pravovoy nigilizm $v$ istoriko-ideologicheskom rakurse // Gosudarstvo i pravo. 1993. № 8.

32. Matuzov N.I. Pravovoy nigilizm i pravovoy idealizm kak dve storony «odnoy medali» // Pravovedenie. 1994, № 2.

33. 33.Matuzov N.I. Pravovoy nigilizm kak yavlenie rossiyskogo politicheskogo mentaliteta // Pravo i zhizn', 2002, № 47.

34. Popov V.V. Nekotorye formy proyavleniya pravovogo nigilizma i puti ikh preodoleniya // Yurist, 2002, № 1.

35. Gorokhov P.A. Sotsial'naya priroda pravovogo nigilizma. Orenburg. 1998.

36. Gulina O.R. Fenomen pravovogo nigilizma v sovremennoy Rossii. Ufa, 2003. 
37. Varlamova N.V. Pravovoy nigilizm: proshloe, nastoyashchee i budushchee Rossii // Konstitutsionnoe pravo. Vostochno-Evropeyskoe obozrenie. 2000, № 1.

38. Gulyaikhin V.N. Pravovoy nigilizm v Rossii. Volgograd, 2005.

39. Zryachkin A.N. Pravovoy nigilizm: prichiny i puti ikh preodoleniya. Saratov, 2009.

40. Chaykin E.V. Sindrom russkogo treugol'nika. Antologiya pravovogo nigilizma v Rossii. M., 2010.

41. Dobrynin N.M. Konstitutsionalizatsiya-ozhidaemoe ili norma zhizni? // Gosudarstvo i pravo. 2010. № 5.
42. Vasil'ev V.I. Garantii est', a vykhoda - net. Osnovnoy zakon strany uzhe ne otvechaet zaprosam na peremeny // NG - Politika. 2012. 6 marta.

43. Reforma Konstitutsii RF - yashchik Pandory ili nasushchnaya neobkhodimost'? // NG-Politika, 2012, 17 aprelya.

44. Il'in I.A. Nashi zadachi. M., 1993. S. 182.

45. Bondarev A.S. Pravovaya antikul'tura v pravovom prostranstve obshchestva. Perm', 2006.

46. Bondarev A.S. Yuridicheskaya otvetstvennost' i bezotvetstvennost' - storony pravovoy kul'tury i antikul'tury sub'ektov prava. SPb, 2008. 